\title{
3-4 インクジェットプリンタ
}

\section{都 築 光 雄 $^{\dagger}$}

\section{1. まえがき}

“パソコン”や“ワープロ”の普及によって, 従来ビ ジネス用中心であったプリンタは，パーソナル用とし ても広く使われるようになった。これらプリンタとし ては, より小型・低価格で, しかもより高速・高印字 品質なものが求められてきた。ささら，ホームビデオ システムの進展, ファクシミリの普及, 電子スチルカ メラの実用化, 高精細テレビの開発などによって各種 の映像情報がより身近なものになってきた結果, プリ ン夕に対して文字や図形だけでなく階調画像やカラー 画像も出力できる高機能が求められている.

インクジェット記録技術は，微細なノズルからイン クを記録紙に向けて噴射制御し，直接的に文字や画像 を記録するものである. 特に, 必要な色の数だけノズ ルを用意するだけで容易にカラー化に対応できること から，ピクトリアルハードコピーを指向した高画質化 に応えうる有力記録技術のひとつとして, 盛んに開発 が進められている。

ここでは, 各種インクジェット方式について, 現在 までに提案された代表的なものを紹介する．

\section{2. インクジェット記録方式}

インクジェット技術の歴史を見ると, 1750 年代に インクジェット物理についての研究がなされたのが最 初と考えられており，1870年代から 90 年代にかけ て，今日のインクジェット技術開発の基礎となってい る理論はほとんど確立されている。しかし, 実用装置 に応用しようとする試みが顕著に現れてきたのは, よ うやく 1930 年代に入ってからのことである. 我が国 では, 1970 年代に入ってからインクジェットによる 実用的なプリンタやファクシミリが現れてきた。しか し，本格的な実用化の兆しが見えてきたのは，ごく最 近のことである.

古い歴史にもかかわらず実用化が遅れた最大の理由

†日本電気株式会社 機能エレクトロニクス研究所

“3-4 Ink Jet Printer" by Mitsuo Tsuzuki (Functional Devices

Research Laboratories, NEC Corp., Kawasaki)

$1236(60)$
は, なんといっても目詰まり等による保守信頼性の問 題である．また微細ノズルの精密加工が容易ではなか ったこと等も理由としてあげられる。しかし，インク ジェット記録技術は, 紙面に直接記録を行ういわゆる 1 次発色性であること, 静肃性に優れること, 曲面等 への記録も可能なこと, カラー化が容易なこと等々, 他の記録技術では得難い魅力を有しており，多くの技 術者を引き付けてきた。

インクジェット記録を行うには, 微細なノズルから インクを記録紙に向けて飛ばすためのインク噴射手 段, 文字等を形成するために記録紙へのインク付着を 制御する変調手段，および記録紙面に順次記録を進め るための走査手段とが必要である. 表 1 に各種インク ジェット方式と代表的な開発企業を示す．種類が多い ように見えても，インク噴射方法については圧力によ る押出しと静電力による引出しの 2 つしかない. 表 1 に示した各種インクジェット方式について, 特に階調 記録に適したインクジェット技術を中心に概説する。

\section{1 連続噴射方式}

高圧ポンプを用いて加圧したインクをノズルに導 き，ノズルから噴射させる．噴流に超音波振動を加え ることにより,インク滴の体積や周期が一定した精密 な粒子化が実現される。1滴で 1 ドットを形成する荷 電制御方式 ${ }^{1)}$ と, 複数滴で 1 ドットを形成する Hertz 方式 ${ }^{2)}$ に大別される.

インク供給圧力や振動の振幅等を適切に設定する と, メインのインク滴形成に続いて小径のサテライト 滴が形成される。このサテライト滴のみ選択して荷電 制御し記録に使用するマイクロドット式は, メイン滴 を用いる場合の $3 \sim 4$ 倍の高精細化が可能である. 図 1 にマイクロドット式の構成を示す ${ }^{3)}$. 偏向用直流電 圧に信号電圧が重畳されて制御電極に印加され, 帯電 されたサテライト滴は速やかに偏向される、記録密度 はノズル径 $65 \mu \mathrm{m}$ のとき 16 ドット $/ \mathrm{mm}, 35 \mu \mathrm{m}$ の とき 40 ドット $/ \mathrm{mm}$ であり , 2 值面積階調法により高 画質のフルカラー記録を得た。

Hert $z$ 方式は, 内径十数 $\mu \mathrm{m}$ というノズルから 4 、 $\mathrm{MPa}$ 程度に加圧したインクを噴出するもので, 速度

テレビジョン学会誌 Vol. 43, No. 11 (1989)pp. 1236〜1241 
表 1 各種インクジェット方式

\begin{tabular}{|c|c|c|}
\hline \multicolumn{3}{|l|}{ （圧力による押し出し） } \\
\hline \multirow{3}{*}{ ・連続噴射方式一 } & 一荷電制御式 & Mead,A.B.Dick,IBM,NTT, シャープ, 日立 \\
\hline & L-Hertz式 & Applicon,IRIS, ミノルタ \\
\hline & Kyser式 & コニカ,富士通,日電 \\
\hline \multirow{4}{*}{ ・ドロップオンデマンド方式- } & \begin{tabular}{|l} 
Gould式 \\
\end{tabular} & Gould, Siemens, IBM, キヤノン, 日電 \\
\hline & Stemme式 & 松下,東レ,三洋,Tektronix \\
\hline & 上ーバブルジェット式 & キャノン,H.P. \\
\hline & L & Olivetti \\
\hline \multicolumn{3}{|l|}{ （静電力による引き出し） } \\
\hline - 間尔喷射方式 & 一多值偏向式 & Teletype,カシオ \\
\hline 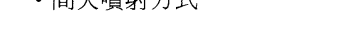 & 一間欠制御式 & 東芝,NTT, 松下 \\
\hline
\end{tabular}

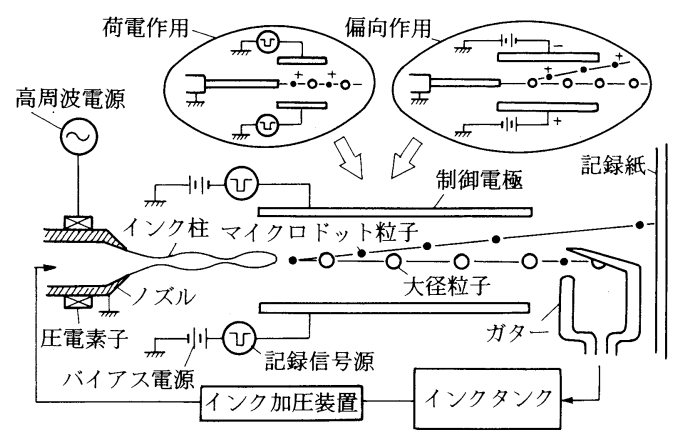

図 1 マイクロドット方式記録ヘッド

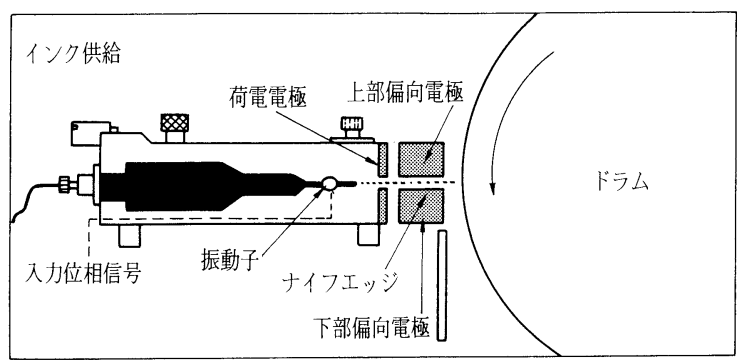

図 2 荷電制御型 Hertz 方式

約 $40 \mathrm{~m} / \mathrm{s}$ のジェットとなり粒子化周波数は約 $1 \mathrm{MHz}$ と, 荷重制御方式に比べて約 1 桁高い.

従来, 帯電変調は数十個のインク滴の束を単位とし て行われた。したがって 1 ドットは多数のインク滴か ら形成されていた。しかし最近, 帯電変調のパルス幅 をインク滴 1 個単位で 1 個から数十個まで制御し, ド ット面積を数十段階に変調できる技術が開発され た ${ }^{4)}$. 図 2 に記録へッド部の構成を示す。ノズル径約 $10 \mu \mathrm{m}$, 粒子化周波数 $1 \mathrm{MHz}$ でドットサイズは 31 段 階に変えられ, 記録密度約 12 ドット $/ \mathrm{mm}$ で 32 階調, 1 画素 $2 \times 2$ マトリクス構成の場合, 解像度 $6 \mathrm{pel} /$ $\mathrm{mm}$ で 128 階調の高画質カラー画像が得られた。

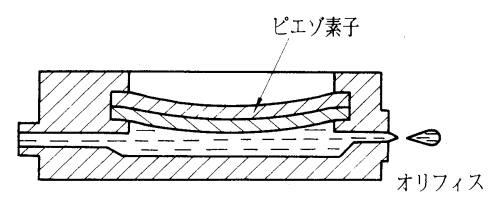

図 3 Kyser式インクジェット素子

\section{2 ドロップオンデマンド方式}

所要時に圧力パルスをインクに加え，1パルス当た り 1 個のインク滴をノズルより射出する. Kyser 式), Gould 式 ${ }^{6)}$, Stemme 式7)はいずれも圧電素子に電圧 を加えたときの歪み効果を利用し，インク室の容積を 変化させて圧力パルスを発生させる. 圧電素子の歪み 量を変えることで比較的容易にインク滴体積を変えら れるため，階調記録に適していると考えられている．

図 3 に, Kyser 式インクジェットの素子構造を示 $す^{5)}$. 平板状の圧電素子をインク室の壁に接着した, いわゆるユニモルフ振動板が圧力パルス発生手段であ る、インク滴を噴射した後のインク補給はノズル部分 の毛細管現象を利用して行われる.このため, 粒子化 周波数は $2 \sim 3 \mathrm{kHz}$ と連続噴射方式に比べ 1 桁以上 小さい，そこで，図4に示すように，多数のノズルを 平面に集積化した，いわゆるマルチノズル化により高 速化を図る試みが盛んである ${ }^{8)}$.ノズル数 $30 \sim 40$ 本, ノズル集積化密度 9 本 $/ \mathrm{mm}$ 程度のものがすでに開発 されている.

Gould 式インクジェット素子は図 5 に示すように, 円筒状の圧電素子を用いる点が特長である ${ }^{6)}$. 圧電素 子がその外壁と内壁の間に電圧を印加したときに径方 向に収縮するのを利用してインクにパルス圧を作用さ せる．この Gould 式インクジェット素子を 8 本用い カラービデオプリンタが開発された ${ }^{9)}$. ユニットに構 成された 8 本の素子は, $\mathrm{Y}$ と Bkに各 1 本ずつ, $\mathrm{M}$ と C には濃度の異なる 3 種のインクを使用するため, 


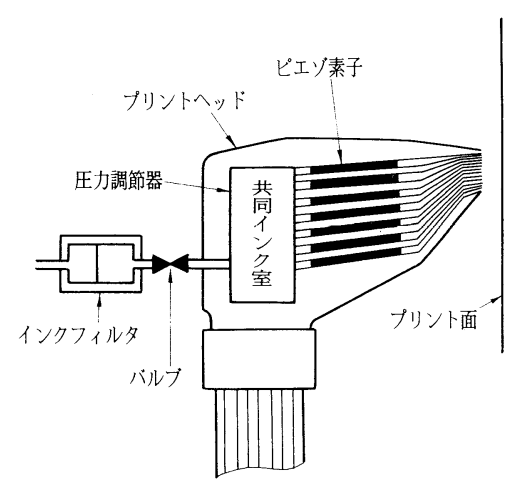

図 4 マルチノズルヘッド

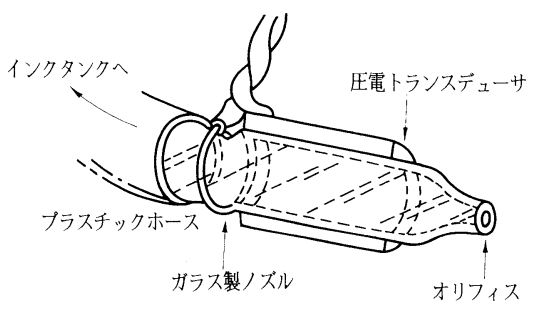

図 5 Gould 式インクジェット素子

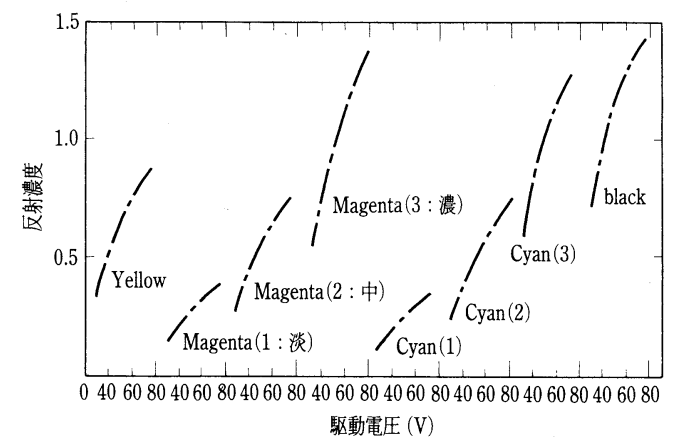

図 6 反射濃度特性

それぞれ 3 本ずつ使われた，各素子では駆動電圧によ りインク滴体積を変調して印字ドットサイズを変化さ せ, 図 6 に示すような反射色濃度特性 (反射率の対数 で定義されるもので, ドット自体の反射濃度は一定で あるが，単位画素に占める面積割合で平均化され擬似 的に濃度が変化する)を得ている，最低濃度以下での 階調表現にはディザ法が併用された．特殊コート紙を 使用し $6.7 \mathrm{pel} / \mathrm{mm}, 64$ 階調の写真なみのカラー記録 が実現された。

Gould 式インクジェット素子の改良型として, 微小 な逆止弁と流体抵抗素子を組込んだマイクロバルブイ ンクジェット素子がある ${ }^{10)}$. 図 7 亿素子構成と動作原

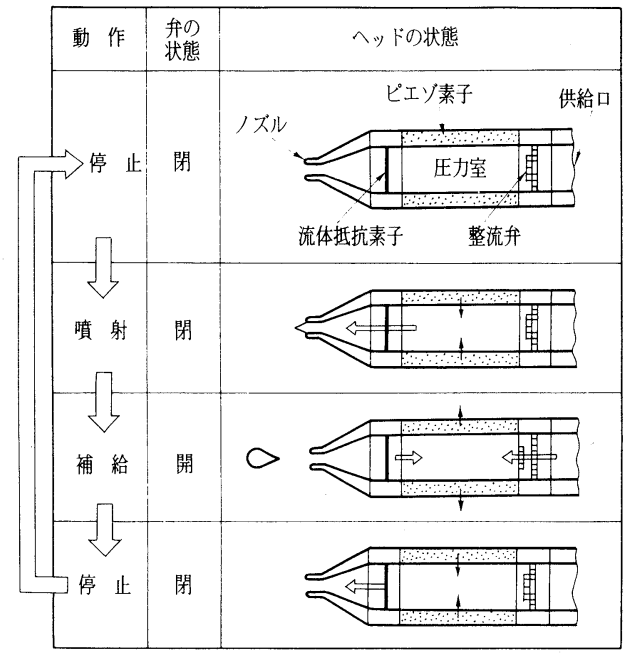

図 7 マイクロバルブインクジェット素子

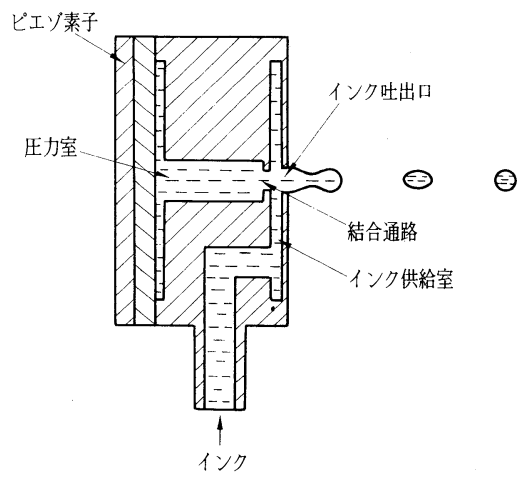

図 8 Stemme 式インクジェット素子

理を示す．逆止弁によるポンプ機能があり，インク補 給をノズル部の毛細管現象に依存する必要がなくなっ たため, $10 \mathrm{kHz}$ までの高い動作周波数が得られた。 さらに，駆動電圧パルス幅に比例してドット面積を 4 倍変化させられる優れた変調特性を実現した。この素 子を用いて高濃度域では多值面積階調法で 48 階調を, また低濃度域では，最小ドットの $4 \times 4$ ディザ法で， 16 階調を再現する複合式により， $8 \mathrm{pel} / \mathrm{mm} ， 64$ 階調 の高品質カラー記録を実現している.

次に, 図 8 はStemme 式インクジェット素子の断 面構造を示したものである7).ノズルが二重になって いる点と，2つのノズル間の隙間からインクが補給さ れる点が特徵となっている。この構造により，ノズル 部へのインク供給が円滑に行われる，松下技研から， 圧力室をホーン型にして圧力伝播の効率を高め,さら に，第 3 のノズルを設け一定流速の空気を流すように した改良型素子も提案され, $20 \mathrm{kHz}$ の高速動作も可 


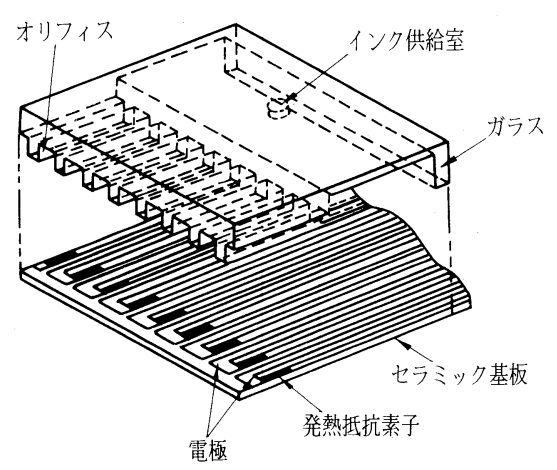

(a) ヘッド構造

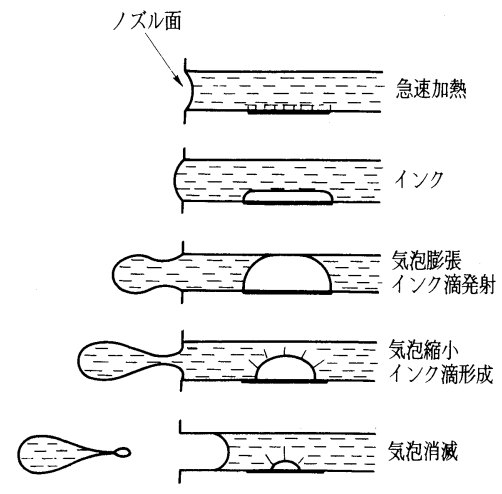

(b) 動作原理

図 9 バブルジェット式(エッジシュータ)

能になっている。この素子を 24 個用い駆動電圧によ る 16 段階のドット径変調と $3 \times 3$ マトリックスを組合 せた多值面積階調法により, $2 \mathrm{pel} / \mathrm{mm}$ と粗いが B 1 サイズの大画面に 64 階調の高品質カラー画像が実現 されている ${ }^{11)}$.

バブルジェット方式は, パルス圧力の発生手段とし てインクを熱パルスで加熱したときの蒸気圧を用いる もので図 9 (a)にヘッド構造, 同図(b)に動作原理を 示す ${ }^{12)}$. 感熱記録へッドと同様の発熱体素子アレイに ノズル列がかぶさった構造をしている．急激な加熱に よる膜沸騰現象を利用して気泡の発生消滅を繰り返し 行わせている. 圧力発生手段が微小なため, 記録へッ ドとして小型にできるうえ 16 ノズル $/ \mathrm{mm}$ 程度に高密 度化が可能であり, カラープリンタなどへの応用が検 討されている.また, 量産化に向いていて低コスト化 も期待できるなど, 今後の重要な記録技術のひとつと して大いに注目される.さらに小型, 低コストという 利点を積極的に活かし, ヘッドを小容量のインクタン クと一体にして使い捨て構造にしたプリンタが市販さ れている ${ }^{13)}$. 図 $10(\mathrm{a})$ にノ゙ル部の素子構造, 同図

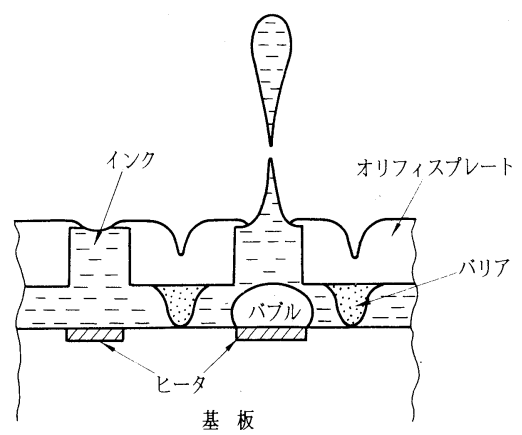

(a) ヘッドノズル部構造

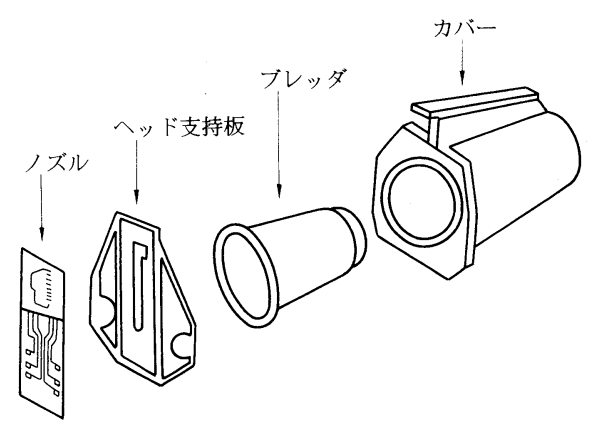

(b) 使い捨てヘッド

図 10 バブルジェット式(サイドシュータ)

(b)に使い捨てへッド構造を示す.

\section{3 間欠噴射方式}

ノズルオリフィスに外に膨らむインクメニスカスを 形成し，ノズルに対向する電極とノズルとの間に高電 圧を印加すると，メニスカスに静電力が作用している 間, インクを系状にノズル外に引出すことができる. 引出したインクを静電偏向して文字を描く方式と, 高 電圧の on-off により系曳を間欠的に制御して記録を 行う方式が提案されている。これらの方式は古くから 実用化の試みがなされてきたが, 高電圧を使う点や動 作状態がメニスカスの状態に大きく影響を受けて安定 性に欠ける点, あるいは高速応答性に欠ける点などが 実用化のネックになっていた。しかし最近, 図 11 に 示す構造で空気流を補助的に使用し, 安定性や応答性 の向上を図ったインクジェットヘッドが検討されてい $3^{4)}$. インク吐出口と電極との一体構造によりバイア 不電極と記録電極間の距離を短くできるため, 小さな 電位差 $($ 約 $900 \mathrm{~V}$ ) で大きな静電力が得られ, 最小パル ス幅 $60 \mu \mathrm{s}$ でインク噴射が可能である. 24 マルチノ ズルヘッドが試作されており, $8 \mathrm{pel} / \mathrm{mm}$ で信号パル ス幅を $60 \sim 300 \mu \mathrm{s}$ の範囲で変化させてドット面積変 調を行い，良好な階調カラー記録を得た。 


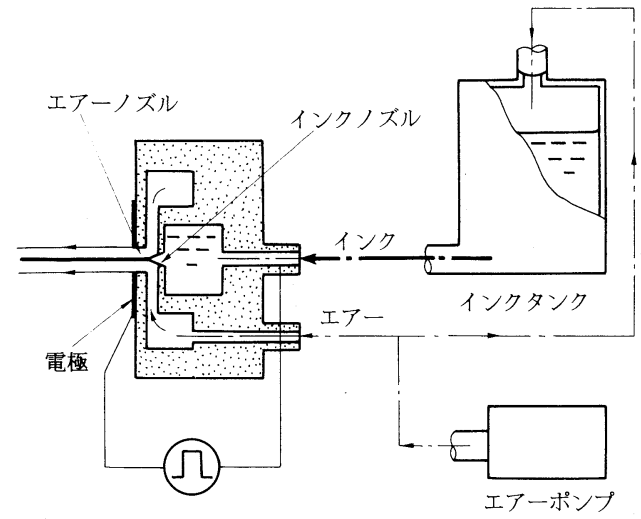

図 11 間久噴射方式(空電制御型)

\section{3. 最近のインクジェット技術の動き}

インクジェット技術は，前節までに述べてきたよう に，インク滴の微細化やサイズ変調技術の向上により 300 400 dpi の高解像度や 64 段階前後の階調再現等, 高画質化という面では充分満足できるレべルに達して いると思われる.しかし, 記録速度が遅いという課題 が残されている．この課題を解決するため，ノズルの マルチ化が試みられてきたが, 実装密度が上がらな い，信頼性が低下する，製造歩留まりが低下する等の 問題により, 多くはノズル数が 50 本前後, 一部で 200 本程度のシリアルタイプのものが実用化されたに 過ぎない. 最近, これらの問題の解決を試み, ライン タイプを狙ったいくつかの方式の提案がみられたので 紹介する。

\section{1 メッシュ方式}

エルム社 ${ }^{15)}$ より提案されたもので, サーマルヘッド とメッシュフィルムを使ったインクジェット方式であ る。基本的な構造図を図 12 に示す ${ }^{16)}$.この方式は, あらかじめインクを充填してあるメッシュフィルムを サーマルヘッドのヒータ面に押し当てる．ヒー夕加熱 によりメッシュ内インクを急激に蒸発させる。その力 でメッシュからインクを吐出させ，記録紙に印字する ものである.この方式は, 従来のインクジェットの課 題である目詰まりに対し, 利点を持つ. 1 つの発熱素 子に複数のフィルム孔が対応しているため, 目詰まり 等により1つの孔からインクが吐出しない場合にも他 の孔からのインク粒子にてドットが形成されるので, ドットぬけが生じにくい.

\section{2 スリットノズル型サーマルインクジェット}

\section{方式}

従来のインクジェットヘッドは発熱素子毎に独立し

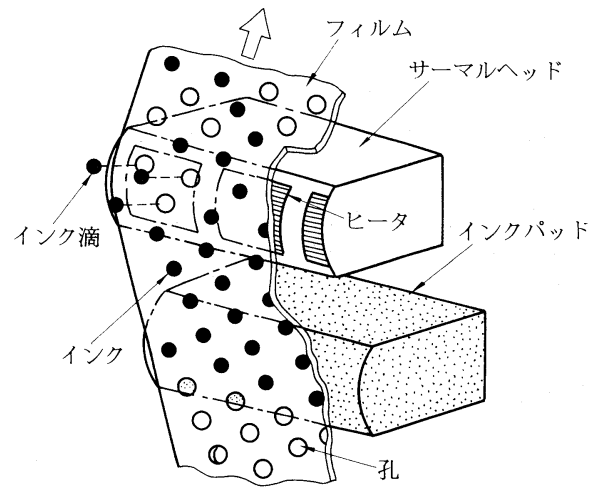

図 12 メッシュ方式

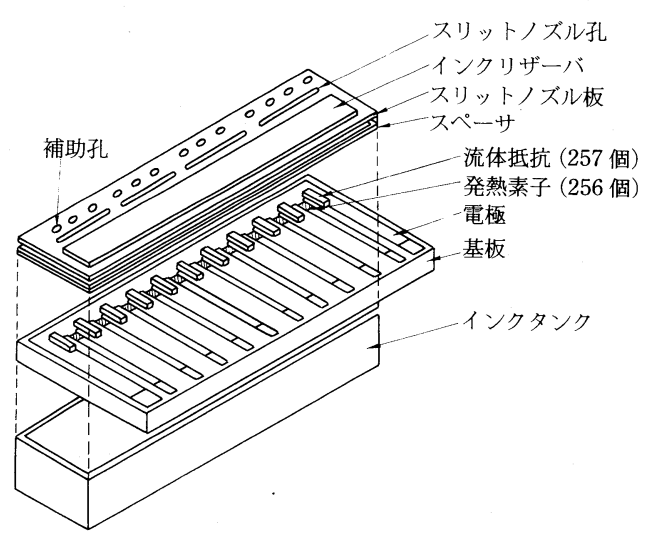

(a) ヘッド構造

(1)

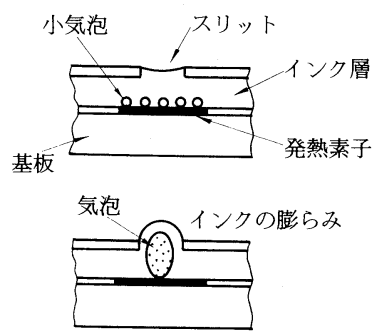

(3)

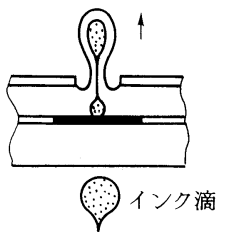

(4)

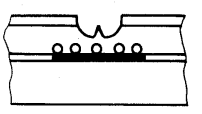

（b）動作原理

図 13 スリットノズル型サーマルインクジェット方 式 


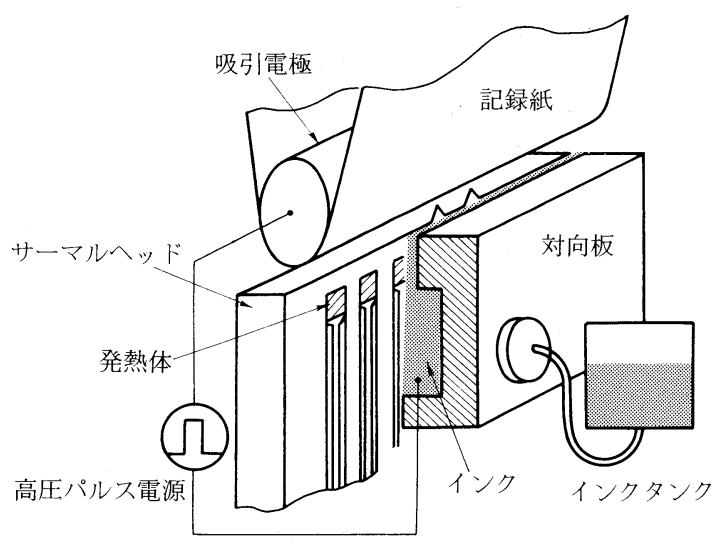

図 14 熱制御型静電吸引スリットジェット

たインク室とノズル孔を備えている，長尺化する場合 多数の発熱素子とノズル孔等を精度良く位置合わせす ることは困難であった。この点を図 13 (a) に示すよう なヘッド構造として, 個別ノズル孔の代わりに複数の 発熱素子でスリット状ノズルとインク室を共用するこ とで解決している ${ }^{17)}$.この方式では，ノズル孔の加工 やノズルと発熱素子を形成した基板との位置合わせも 簡単になる，吐出原理を図 $13(\mathrm{~b})$ に示す。発熱素子に よる加熱でインクが急激に蒸発し，基板に垂直な方向 への力により発熱素子の前面およびスリット内のイン ク層を押上げる．インク層の一部は風船のように引き ちぎれてインク滴として吐出する。この方式では, 基 板に垂直な方向に集中した力をインク層に作用させる ことが重要で，そのために発熱素子の周囲に流体抵抗 素子を配置している。

\section{3 熱制御型静電吸引スリットジェット}

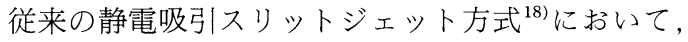
インクの選択的な吸引の制御には $100 \mathrm{~V}$ 以上の高電 圧が必要とされていたが, 熱制御型静電吸引スリット ジェット方式 ${ }^{19)}$ は, インクに静電吸引力を印加してお き加熱によるインク物性值の温度依存性を吸引制御に 利用するもので，図 14 にその原理図を示す，この方 式では従来のサーマルヘッドを活用できるうえ，スリ ット状ノズルのため長尺化が容易, 高沸点インクを用 い目詰まりを起こしにくい等, インクジェットの課題 をクリアしている.

\section{4. むす び}

ピクトリアルハードコピーを得るための階調記録に 適したインクジェット記録技術を中心に概説した．

インクジェットは個人用から業務用まで多くの分野 での活用が期待されているが，実用性の観点からはま
だ不満が多い,インクジェット技術開発には、ヘッ ド, 記録紙，インクの三者一体となった総合的な改 良・最適化が不可欠である。特に材料面での改良検討 は真の実用化を果たすうえでの最重要課題である，実 用性向上のための検討は地道に進歩してきており, こ れら課題を解決し, 今後とも記録技術の重要な担い手 として発展するであろうことを確信している.

(1989 年 8 月 9 日受付)

\section{〔参 考 文 献〕}

1) R. G. Sweet: "High-Frequency Recording with Electrostatically Deflected Ink Jet”, Rev. Sci. Instr., 36, 2, pp. 131 -136 (1965)

2) C. H. Hertz, et al. : "A Method for the Intensity Modulation of a Recording Ink Jet and Its Applications", Acta Univ. Lund., 2, 15, pp. 1-16 (1967)

3）山田ほか：“マイクロドット・インクジェット記録方式によ る高精細フルカラー画像記録の検討”, 画像電子学会研究会, 82-14-1 (1982)

4) C. H. Hertz, et al. : "Ink Jet Printing of Photographic Quality Color Images", The 4th Intl. Cong. on Advances in NIP Tech. (1988)

5) E. L. Kyser, et al. : U. S. Pat. 3, 946, 398 (1969)

6) S. I. Zoltan : "Pulsed Droplet Ejection Syster", U. S. Pat. 3, 683, 212 (1972)

7) E. Stemme, et al. : "The Piezoelectric Capillary Injector -A New Hydrodynamic Method for Dot Pattern Generation", IEEE Trans., ED-20, 1, pp. 14-19 (1973)

8）笠原ほか：“圧力制御式インクジェットプリンタ”, 画電学誌, 10, 3, p. 182 (1981)

9）下田ほか：“ドット径制御可能なインクジェット記録ヘッ ド”, 信学技報, ED85-27, p. 93 (1985)

10）都築ほか：“マイクロバブルヘッドによる高品質インクジェ ットフルカラー記録”, 第.1回 NIP 技術シンポジウム, p. 135 (1984)

11）竹原ほか：“高品位カラーインクジェットプリントシステ 厶”, 第 1 回 NIP 技術シンポジウム, p. 153 (1984)

12）原ほか: “バブルジェット記録”, 画電学誌, 11,2, p. 66 (1982)

13) HP Journal, 36, 5 (1985)

14）三浦ほか：“空気流と静電力を用いたインクジェットト記録 ヘッド”, 第 1 回 NIP 技術シンポジウム, p. 131（1984）

15）特願昭 60-71620

16）服部ほか：“サーマルヘッドと有孔フィルムを用いたインク ジエット記録方式”, 第 4 回 NIP 技術シンポジウム, p. 81 (1987)

17）桜井ほか：“ライン走查型サーマルインクジェットデバイ 又”, 平 1 信学総全大, C-78 (1989)

18）一之瀬ほか：“スリットジェット記録方式”, 第 1 回 NIP 技 術シンポジウム, p. 123 (1984)

19）斎藤ほか：“熱制御型静電吸引スリットジェット”, Japan Hardcopy'89, pp. 217-220 (1980) 